\title{
Triptolide Inhibits Lipopolysaccharide-Induced MUC5AC/5B Expression via Nuclear Factor-Kappa B in Human Airway Epithelial Cells
}

\author{
Bo Hyeon Seo ${ }^{1}$, Tae Yeong Choi ${ }^{1}$, Yoon Seok Choi ${ }^{1}$, Chang Hoon Bae ${ }^{1}$, \\ Hyung Gyun $\mathrm{Na}^{1}$, Si-Youn Song ${ }^{1}$, and Yong-Dae Kim ${ }^{1,2}$ \\ ${ }^{1}$ Department of Otorhinolaryngology-Head and Neck Surgery, College of Medicine, Yeungnam University, Daegu; and \\ ${ }^{2}$ Regional Center for Respiratory Diseases, Yeungnam University Medical Center, Daegu, Korea
}

\section{사람 호흡기 상피세포에서 Triptolide의 Nuclear Factor-Kappa B를 통한 Lipopolysaccharide로 유도된 MUC5AC/5B 발현 억제 효과}

서보현 ${ }^{1} \cdot$ 최태영 ${ }^{1} \cdot$ 최윤석 ${ }^{1} \cdot$ 배창훈 $^{1} \cdot$ 나형균 $^{1} \cdot$ 송시연 $^{1} \cdot$ 김용대 $^{1,2}$

영남대학교 의과대학 이비인후-두경부외과학교실, ${ }^{1}$ 영남대학교병원 권역 호흡기 전문질환센터 ${ }^{2}$

\author{
Received March 27, 2018 \\ Revised June 18,2018 \\ Accepted June 28, 2018 \\ Address for correspondence \\ Yong-Dae Kim, MD, PhD \\ Department of Otorhinolaryngology- \\ Head and Neck Surgery, \\ College of Medicine, \\ Yeungnam University, \\ 170 Hyeonchung-ro, Nam-gu, \\ Daegu 42415, Korea \\ Tel $+82-53-620-3781$ \\ Fax $+82-53-628-7884$ \\ E-mail ydkim@med.yu.ac.kr
}

Background and Objectives The representative mucin genes in the human airway are MUC5AC and MUC5B, which are regulated by several inflammatory and anti-inflammatory substances. Triptolide (TPL), udenafil, betulinic acid, changkil saponin, and glucosteroid are some of the many anti-inflammatory substances that exist. TPL is a diterpenoid compound from the thunder god vine, which is used in traditional Chinese medicine for treatment of immune inflammatory diseases, such as rheumatoid arthritis, systemic lupus erythematosus, nephritis and asthma. However, the effects of TPL on mucin expression of human airway epithelial cells have yet to be reported. Hence, this study investigated the effect of TPL on lipopolysaccharide (LPS)-induced MUC5AC and MUC5B expression in human airway epithelial cells.

Subjects and Method The NCI-H292 cells and the primary cultures of human nasal epithelial cells were used to investigate the effects of TPL on LPS-induced MUC5AC and MUC5B expression using real-time polymerase chain reaction, enzyme immunoassay, and Western blot. Results TPL significantly decreased the LPS-induced MUC5AC and MUC5B mRNA expression and protein production. TPL also significantly decreased the nuclear factor-kappa $\mathrm{B}$ (NF-kB) phosphorylation.

Conclusion These results suggest that TPL down regulates MUC5AC and MUC5B expression via inhibition of NF-kB activation in human airway epithelial cells. This study may provide important information about the biological role of triptolide on mucus-secretion in airway inflammatory diseases and the development of novel therapeutic agents for controlling such diseases. Korean J Otorhinolaryngol-Head Neck Surg 2018;61(12):674-80

Key Words Human airway epithelial cells · MUC5AC · MUC5B · Nuclear factor-kappa B · Triptolide.

\section{서 론}

점액 유전자는 고분자 당단백인 점소(mucin) 생성을 조절
하여 점액(mucous)의 생화학적, 물리화학적 또는 유동학적 특성을 결정하는 큰 역할을 한다. ${ }^{1)}$ 기도 내 점액은 기도의 적 절한 습도를 유지해주고, 윤활작용을 하며, 섬모운동을 통해

This is an Open Access article distributed under the terms of the Creative Commons Attribution Non-Commercial License (https://creativecommons.org/licenses/by-nc/4.0) which permits unrestricted non-commercial use, distribution, and reproduction in any medium, provided the original work is properly cited. 
기도 점막에 부착된 외부물질을 배출시켜주어 물리적 방어 벽 역할을 한다. 그러나 급성 또는 만성 염증성 호흡기 질환 에서는 점액의 분비가 과도하게 일어나고 그 성상이 변화되어 서 병의 경과를 악화시킬 수 있으므로 점액 과분비를 조절하 는 것이 매우 중요하다. ${ }^{12)}$ 점액 유전자는 현재까지 약 20 개가 발견되었고, 이 중 호흡기 상피의 배상세포에서 분비되는 MU$\mathrm{C} 5 \mathrm{AC}$ 와, 점막 하 분비샘에서 배출되는 MUC5B가 대표적인 호흡기의 분비형 점소다. ${ }^{3-5)}$

호흡기 상피세포에는 점액 유전자 발현과 점액 분비를 증 가시키는 여러 가지 물질이 존재한다. ${ }^{4,6-9)}$ 그중 그람 음성 세 균의 외막 성분인 lipopolysaccharide(LPS)는 toll like receptor 4 를 활성화시키고, mitogen activated protein kinase 와 nuclear factor-kappa $\mathrm{B}(\mathrm{NF}-\mathrm{kB})$ 경로를 통하여 케모카 인의 대식세포를 자극하고, 사이토카인의 신호를 증폭시키 고, 백혈구와 림프구의 이동을 유도함으로써 여러 염증반응 을 일으킨다. ${ }^{10,11}$

Triptolide(TPL)는 화살나무과의 덩굴성 식물인 뇌공등 (Tripterygium wilfordii Hook F)에서 추출되는 탄소수가 20개인 diterpenoid 계열의 triepoxid 중합체이다. 뇌공등은 중국에서 수 세기 동안 자가면역질환과 관련된 류마티스 관 절염, 루푸스, 신장병과 천식 등의 치료제로 사용되어 왔으 며, TPL은 최근 연구를 통해 항염작용과 면역억제작용, 항암 작용을 하는 것으로 알려져 있다. 또한 TPL은 염증 매개 유 전자 NF-kB가 DNA와 결합하는 것을 차단하여 염증이 진 행되는 것을 막고, 염증을 일으키는 유전자를 차단하는 것 으로 알려져 있다. ${ }^{12,13)}$ 그러나 사람에서 염증반응에 의한 기 도 점액 과분비 과정에 TPL이 점액 유전자 발현에 어떤 영 향을 미치는지에 대한 연구는 보고된 바가 매우 미흡한 실정 이다. ${ }^{14)}$ 따라서 호흡기 상피세포에서 TPL이 점액 유전자의 발현과 점액 단백 생성에 어떠한 영향을 미치는지와 어떠한 경로를 통하여 점액 유전자 발현이 되는지 알아보고자 본 연 구를 시행하였다.

\section{대상 및 방법}

\section{재 료}

LPS와 TPL은 Sigma(St. Louis, MO, USA)에서 구입하였 고, 사람 폐의 점액상피양 암 세포주(human pulmonary mucoepidermoid carcinoma cell line)인 NCI-H292 세포는 American Type Culture Collection(Manassas, VA, USA)에 서 구입하였다. RPMI 1640 medium은 Invitrogen(Carlsbad, CA, USA), Fetal bovine serum(FBS)은 Hyclone Laboratories(Logan, UT, USA)에서 구입하였다. MUC5AC(SC-20118)
일차 항체와 MUC5B(SC-20119) 일차 항체, anti-rabbit horseradish peroxidase(HRP)-conjugated 이차 항체는 Santa Cruz Biotechnology(Santa Cruz, CA, USA)에서 구입하였다. NFkB p65, phospho-NF-kB p65는 Signaling Technology (Danvers, MA, USA)에서 구입하였다.

\section{세포 배양 및 처치}

사람 호흡기 상피세포의 점액상피양 암 세포주(human pulmonary mucoepidermoid carcinoma cell line)인 NCI-H292 세포를 6-well plate에 $1 \times 10^{6}$ cells/well의 농도로 접종한 후 $1 \%$ penicillin/streptomycin과 $10 \% \mathrm{FBS}$ 가 포함된 RPMI 1640 배지를 이용하여 $95 \%$ 의 산소와 $5 \%$ 의 이산화탄소가 혼합된 완전 습윤 환기된 배양기에서 $37^{\circ} \mathrm{C}$ 의 온도로 배양하 였다. 80 90\% 정도 배양이 이루어지면 세포를 $0.5 \% \mathrm{FBS}$ 가 포함된 RPMI 1640 배지로 교체한 후 24시간 동안 배양한 후, phosphate-buffered saline(PBS)로 세척하고 실험에 사 용하였다.

LPS의 효과를 알아보기 위해서 NCI-H292 세포에 $25 \mathrm{ng} /$ $\mathrm{mL}$, 또는 $50 \mathrm{ng} / \mathrm{mL}, 75 \mathrm{ng} / \mathrm{mL}, 100 \mathrm{ng} / \mathrm{mL}$ 농도의 TPL을 처리한 후 1 시간 뒤에 $100 \mathrm{ng} / \mathrm{mL}$ 농도의 LPS를 각각 투여 하였다. 대조군은 동일한 시간 동안 배지에서 NCI-H292 세 포를 단독으로 배양하였다.

사람 코 점막 상피세포를 얻기 위해서 기저 당뇨병이나 알레 르기 질환과 그 가족력이 없고, 피부단자시험(skin prick test) 과 다중 알레르기항원검사(multiple allergen simultaneous test)에서 음성반응이 나온 10 명을 대상으로 융비술 시행 중에 발생하는 비강 내 적출물 중 정상 하비갑개 조직을 얻었다. 일차 배양을 하기 위해 하비갑개 점막 조직을 $\mathrm{PBS}$ 로 세척한 후, 90분 동안 dispase(Boehringer Mannheim Biochemica, Mannheim, Germany)에 침전시켰다. 외과용 수술칼을 사 용하여 하비갑개 점막의 표면을 벗겨내어, $1 \% \mathrm{PBS}$ 를 추가한 후 mesh를 통해 여과하였다. 이런 과정을 통해 얻은 하비갑 개 점막의 상피세포들을 12-well plate에 접종한 후, EpiLife medium(Cascade Biologics, Portland, OR, USA)과 keratinocyte growth supplement $(5 / 500 \mathrm{~mL}$ of medium, Cascade Biologics)에서 배양하였다.

본 연구는 본원 임상 시험 심사 위원회(Institutional Review Board)의 승인을 받아 시행하였다(IRB No. YUMC 201710-021).

\section{Real-time polymerase chain reaction(Real-time PCR) 분석}

모든 RNA는 GeneAmp RNA polymerase chain reaction 
(PCR) Cored Kit(Applied Biosystems, Carlsbad, CA, USA) 를 이용하여 $\mathrm{cDNA}$ 로 역전사되었다. 실험에 사용된 primer의 염기서열은 MUC5AC 점액 유전자의 경우 sense는 5'-TCA ACG GAG ACT GCG AGT ACA C-3, antisense는 5'-CTT GAT GGC CTT GGA GCA-3'이고, MUC5B 점액 유전자의 경우 sense는 5'-CAC ATC CAC CCT TCC AAC-3', antisense는 5'-GGC TCA TTG TCG TCT CTG-3'이며, 각 반응 의 내부 양성 대조군(internal positive control)은 glyceraldehyde-3-phosphate dehydrogenase(GAPDH)를 사용하였 으며, 염기서열은 sense는 5'-CCT CCA AGG AGT AAG ACC CC-3', antisense는 5'-AGG GGT CTA CAT GGC AAC $\mathrm{TG}-3$ 이다.

$1 \mu \mathrm{g}$ 의 RNA로 cDNA를 제작하여, 합성된 cDNA로 Realtime PCR을 수행하였다. Real-time PCR은 최종 부피가 10 $\mu \mathrm{L}$ 이고, 농도가 $0.5 \mu \mathrm{M}$ 이 되게 primer를 투여하였으며, $\mathrm{iQ}$ SYBR Green Supermix(Bio-Rad, Hercules, CA, USA)를 이용하여 실험하였다. 정량적인 PCR은 CFX96 Real-Time PCR system C1000 Thermal Cycler(Bio-Rad)를 사용하여 $95^{\circ} \mathrm{C}$ 에서 15 초간 변성(denaturation) 과정을 거치고 $60^{\circ} \mathrm{C}$ 에 서 45초간 결합(annealing) 반응을 시킨 후, 이러한 과정을 40 회 반복하였다. 각 실험에서 증폭된 cDNA의 유무를 확인 하기 위하여 GAPDH를 대조 유전자(internal control)로 사 용하였다.

\section{Enzyme linked immunosorbent assay(ELISA) 분석}

$\mathrm{MUC5AC}$ 점액 단백과 MUC5B 점액 단백의 함량을 측정 하기 위해서 enzyme-linked immunosorbent assay(ELISA) 법을 이용하였다. 시료를 처리한 배양된 세포에서 $200 \mu \mathrm{L}$ RIPA buffer(Thermo Fisher, Rockford, IL, USA)로 단백을 추출하여 정량하였다. 추출한 단백질은 F96 Cert. Maxisorp Nunc-Immuno Plate(Fisher Scientific, Lenexa, KS, USA) 에 코팅한 후 $4^{\circ} \mathrm{C}$ 에서 하룻밤 동안 배양하였다. 다음 과정으 로 비특이적 결합을 방지하기 위해 $2 \%$ bovine serum albumin (BSA)이 포함된 $\mathrm{PBS}$ 에 실온에서 1시간 동안 둔 후 $0.05 \%$ Tween 20을 함유한 PBS로 세척한 다음, 1:200으로 희석된 $\mathrm{MUC5AC}$ 와 MUC5B 일차 항체로 반응시켰다. PBS로 3회 세 척한 후 HRP-conjugated 이차 항체를 1:1000으로 희석하여 각 well에 첨가하였고, 1 시간 후에 각 well을 3 회 세척하였다. $3,3,5,5$-tetramethyl benzidine 용액으로 발색한 후, $2 \mathrm{~N}-$ $\mathrm{H}_{2} \mathrm{SO}_{4}$ 를 이용하여 중단시켰다. ELISA reader(EL800 ${ }^{\circledR}$, BioTek Instruments, Winooski, VT, USA)로 $450 \mathrm{~nm}$ 에서 흡광 도를 측정한 후 결과 값을 100 을 기준으로 나타내었다.

\section{Western blot 분석}

NCI-H292 세포를 6-well plate에 담고 농도에 따라 TPL 을 처리하여 각각 배양하였다. 이후 각 세포들을 $200 \mu \mathrm{L} \mathrm{RIPA}$ buffer를 이용하여 단백질을 모은 다음 $4^{\circ} \mathrm{C}$ 에서 $2500 \times \mathrm{g}$ 으 로 10 분간 원심분리를 시행하여 정제된 상층액을 wholecell lysate로 보관하였다. 이렇게 하여 분리된 $20 \mu \mathrm{g}$ 의 단백 을 10\% reducing sodium dodecyl sulfatepolyacrylamide gel을 이용한 전기영동을 실시하였고, 전기영동된 단백질을 polyvinylidene difluoride membrane으로 옮겨 5\% BSA가 포함된 Tris-buffered saline and Tween-20(TBST)으로 처리 하여 항체와의 비특이적 결합을 억제시킨 후 NF-kB 일차 항 체로 하룻밤 동안 배양하였다. 이후 TBST로 세척하고 antirabbit HRP-conjugated NF-kB 이차 항체로 1시간 반응한 다음 세척한 후 West Pico Chemiluminescent Substrate (Thermo Fisher)를 이용하여 각각의 단백의 띠(band)를 확 인하였다.

확인된 띠의 세기는 Chemiluminescence image system (FUSION-FX7 820wL, Eberhardzell, Garmany)을 이용하 여 반정량적으로 분석하여 상대적인 density로 나타내었다.

\section{통 계}

통계처리는 Windows용 SPSS version 10.0(SPSS Inc., Chicago, IL, USA)을 사용하였다. 모든 실험은 $p$ 값이 0.05 미만인 경우를 유의미한 것으로 정하여 Student t-test와 analysis of variance test, Mann-Whitney U test를 이용하 였다.

\section{결 과}

\section{NCI-H292 세포에서 TPL이 LPS에 의해 유도된 MUC5AC와 MUC5B mRNA 발현에 미치는 영향}

NCI-H292 세포에서 TPL이 LPS에 의해 유도된 MUC5AC 와 MUC5B mRNA 발현에 미치는 영향을 알아보기 위하여 NCI-H292 세포에 TPL을 다양한 농도로 처치하고, LPS에 의해 유도된 MUC5AC와 MUC5B mRNA 발현을 Real-time $\mathrm{PCR}$ 을 이용하여 분석하였다. LPS에 의해 유도된 MUC5AC 와 MUC5B mRNA 발현은 TPL을 투여한 군에서 통계적으 로 유의미하게 감소하였다(Fig. 1A and B).

\section{NCI-H292 세포에서 TPL이 LPS에 의해 유도된 MUC5AC와 MUC5B 점액 단백 생성에 미치는 영향}

NCI-H292 세포에서 TPL이 LPS에 의해 유도된 MUC5AC 와 MUC5B 점액 단백 형성에 미치는 영향을 알아보기 위하 

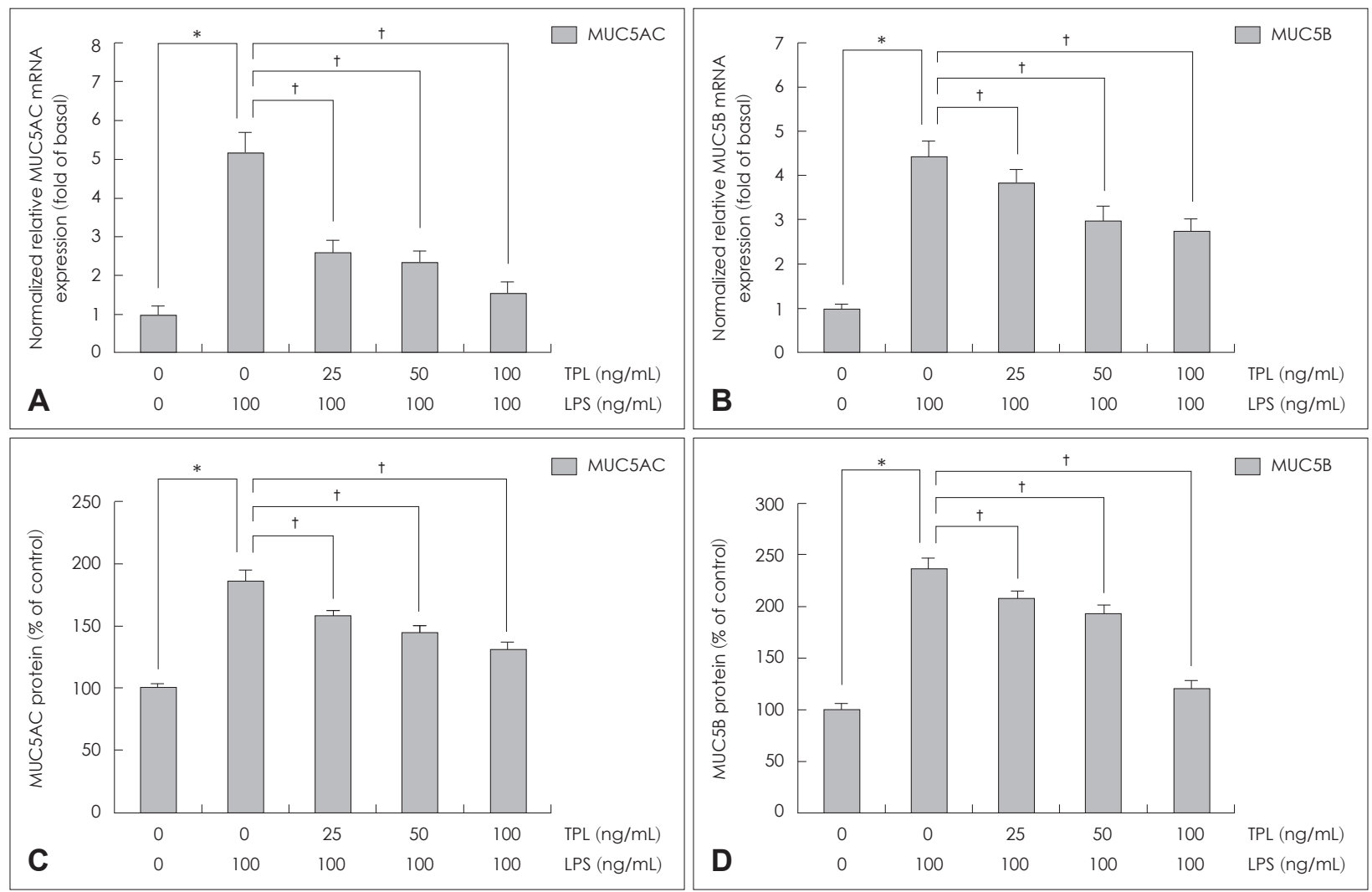

Fig. 1. Effects of TPL on LPS-induced MUC5AC and MUC5B expression in human NCl-H292 cells. Results of real time polymerase chain reaction showed that TPL significantly decreased LPS-induced MUC5AC and MUC5B mRNA expression (A and B). Enzyme-linked immunosorbent assay showed that TPL significantly decreased LPS-induced MUC5AC and MUC5B protein production at 48 hours after exposure of TPL (C and D). The images are representative of three separate experiments performed in triplicated. Bars indicate the mean \pm standard deviation of three independent experiments performed in triplicate. ${ }^{*} p<0.05$ compared with zero value, ${ }^{\dagger} p<0.05$ compared with LPS only. TPL: triptolide, LPS: lipopolysaccharide.

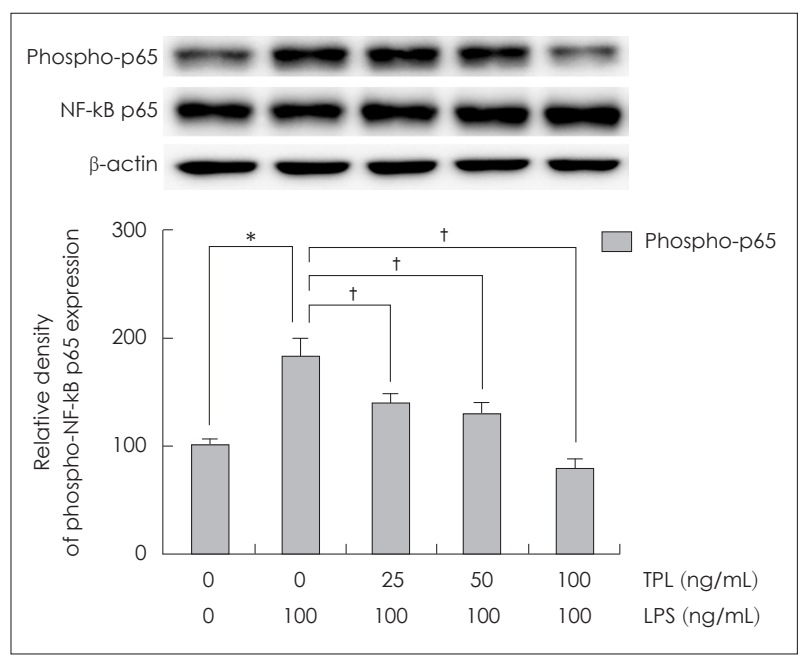

Fig. 2. Effects of TPL on phosphorylation of LPS-induced NF-kB p65 in human $\mathrm{NCl}-\mathrm{H} 292$ cells. Western blot showed that TPL significantly decreased the LPS-induced phosphorylated NF-kB p65 level. The images are representative of three separate experiments performed in triplicated. Bars indicate the mean \pm standard deviation of three independent experiments performed in triplicate. ${ }^{*} p<0.05$ compared with zero value, ${ }^{\dagger} p<0.05$ compared with LPS only. TPL: triptolide, LPS: lipopolysaccharide, NF-kB p65: nuclear factor-kappa B p65.
여 NCI-H292 세포에 TPL을 다양한 농도로 처치하고, 48시 간 동안 배양한 후 ELISA 법을 시행하였다. LPS에 의해 유 도된 MUC5AC와 MUC5B 점액 단백 생성은 TPL을 투여한 군에서 통계적으로 유의미하게 감소하였다(Fig. $1 \mathrm{C}$ and D).

\section{NCI-H292 세포에서 TPL이 LPS에 의해 유도된 NF-kB $\mathrm{p} 65$ 인산화에 미치는 영향}

Western blot 분석 결과 LPS로 유도된 NF-kB p65의 인 산화는 TPL 농도의 증가에 따라 유의미하게 감소하는 양상 을 보였다(Fig. 2).

\section{사람 코 점막 세포에서 TPL이 LPS에 의해 유도된 MUC5AC와 MUC5B mRNA 발현에 미치는 영향}

사람 코 점막 세포에서 TPL이 LPS에 의해 유도된 MU$\mathrm{C} 5 \mathrm{AC}$ 와 MUC5B mRNA 발현에 미치는 영향을 알아보기 위 하여 배양된 사람 코 점막 상피세포에 다양한 농도의 TPL을 처치하고, LPS에 의해 유도된 MUC5AC와 MUC5B mRNA 발현을 Real-time PCR을 이용하여 분석하였다. LPS에 의해 

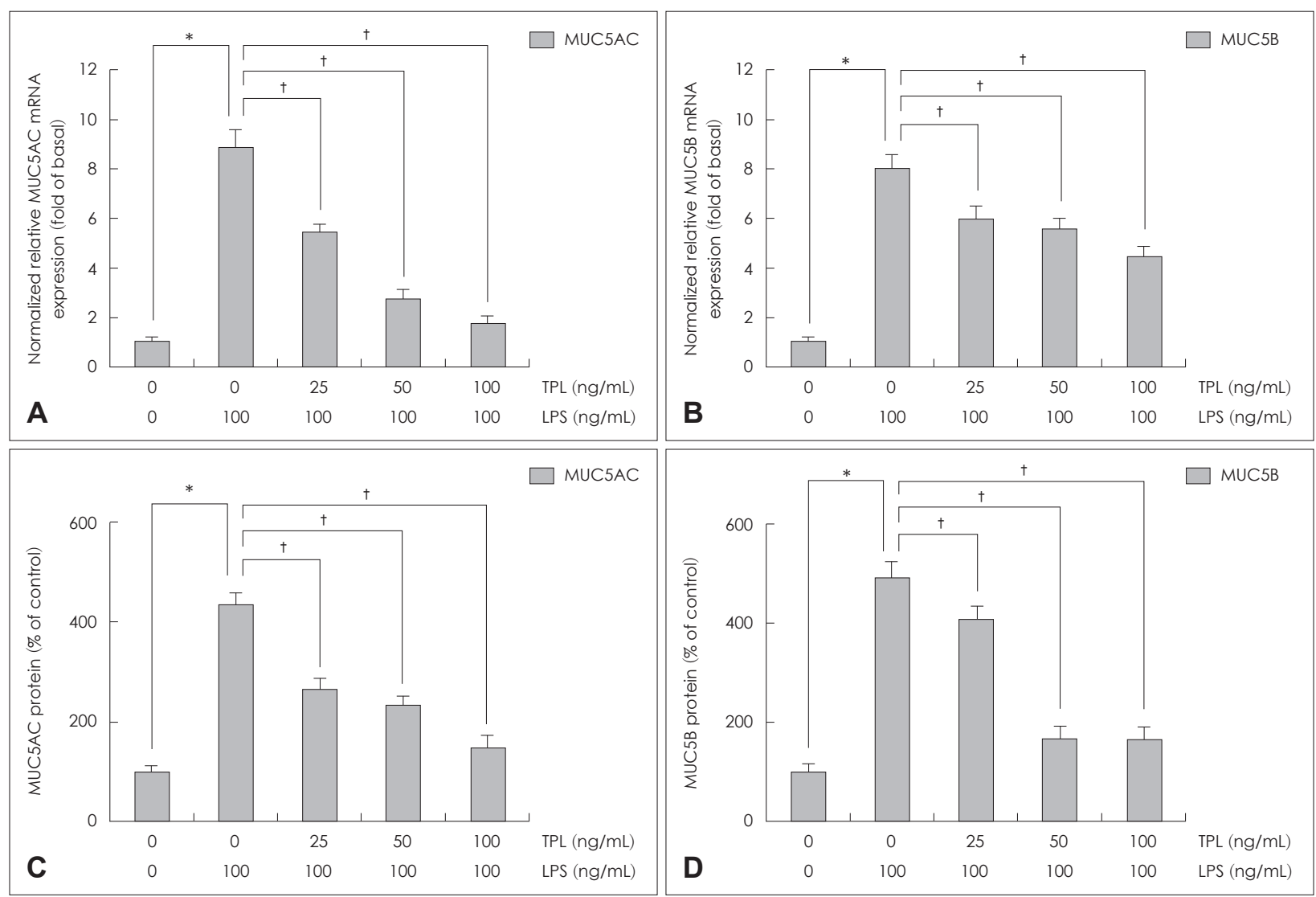

Fig. 3. Effects of TPL on LPS-induced mucin genes expression and protein production in human nasal epithelial cells. Results of real time polymerase chain reaction showed that TPL significantly decreased LPS-induced MUC5AC and MUC5B mRNA expression (A and B). Enzyme-linked immunosorbent assay showed that TPL significantly decreased LPS-induced MUC5AC and MUC5B protein production at 48 hours after exposure of TPL (C and D). The images are representative of three separate experiments performed in triplicated. Bars indicate the mean \pm standard deviation of three independent experiments performed in triplicate. ${ }^{*} p<0.05$ compared with zero value, ${ }^{\dagger} p<0.05$ compared with LPS only. TPL: triptolide, LPS: lipopolysaccharide.

유도된 MUC5AC와 MUC5B mRNA 발현은 TPL을 투여한 군에서 통계적으로 유의미하게 감소하였다(Fig. 3A and B).

\section{사람 코 점막 세포에서 TPL이 LPS에 의해 유도된 MUC5AC와 MUC5B 점액 단백 생성에 미치는 영향}

NCI-H292 세포에서 TPL이 LPS에 의해 유도된 MUC5AC 와 MUC5B 점액 단백 형성에 미치는 영향을 알아보기 위하여 배양된 사람 코 점막 상피세포에 다양한 농도의 TPL을 처치하 고, 48시간 동안 배양한 후 ELISA 법을 시행하였다. LPS에 의 해 유도된 MUC5AC와 MUC5B 점액 단백 생성은 TPL을 투여 한 군에서 통계적으로 유의미하게 감소하였다(Fig. $3 \mathrm{C}$ and D).

\section{사람 코 점막 세포 세포에서 TPL이 LPS에 의해 유도된 $\mathrm{NF}-\mathrm{kB}$ p65 인산화에 미치는 영향}

Western blot 분석 결과 LPS로 유도된 NF-kB p65의 인산 화는 TPL을 투여한 군에서 통계적으로 유의미하게 감소하였 다(Fig. 4).

\section{고 찰}

그람 음성 세균의 외막에 존재하는 LPS는 염증반응을 일 으키고, 이러한 염증반응 과정에서 일어나는 NF-kB 의 활성 화와 점액 유전자 발현을 억제하는 다양한 항염증 물질들이 있으며, 그 예로 TPL, udenafil, betulinic acid, changkil saponin, glycyrrhizin, carbenoxolone, silibinin, glucosteroid 등이 알려져 있다. ${ }^{3,15-20)}$

이들 중 TPL은 수 세기 전부터 항염증제로 사용되어 왔 다. ${ }^{21)} \mathrm{TPL}$ 의 항염증 기전에 대한 최근 연구를 보면 TPL은 세포핵 내에서 Purine-box/NF-activated T-cell에서의 전사 활성화와 $\mathrm{NF}-\mathrm{kB}$ 에서의 전사 활성화를 차단하여 DNA와의 결합을 차단하고, T-cell의 Interleukin(IL)-2 발현을 억제하 여, 림프구의 활성을 억제함으로써 항염증 작용을 나타낸다. ${ }^{13)}$ IL-2 이외에도, phorbol 12-myristate 13-acetate에 의해 활 성화되는 염증 사이토카인인 tumor necrosis factor- $\alpha$, IL-6, IL-8, macrophage inflammatory protein-2 $\alpha$, intercellular 


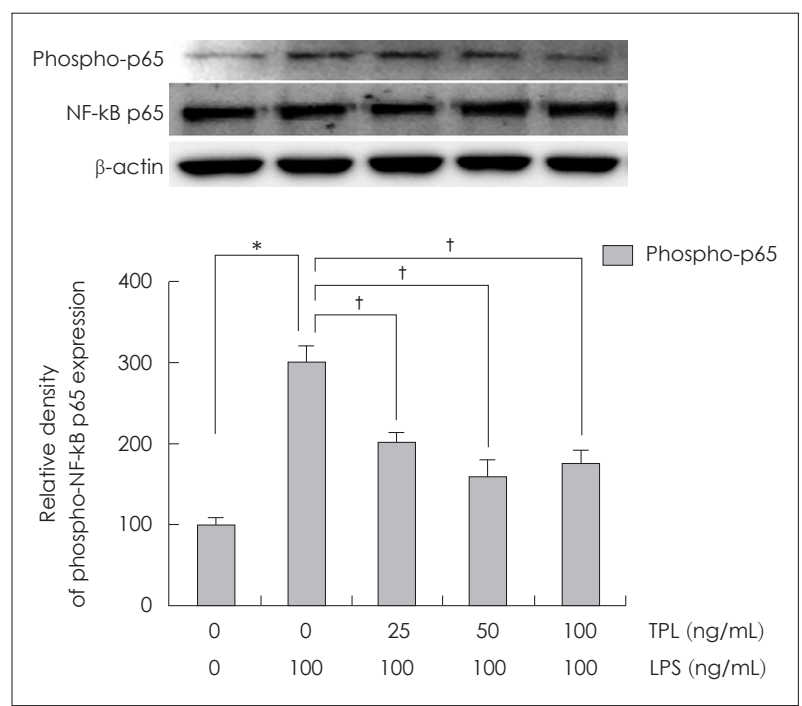

Fig. 4. Effects of TPL on phosphorylation of LPS-induced NF-kB p65 in human nasal epithelial cells. Western blot showed that TPL significantly decreased the LPS-induced phosphorylated NFkB p65 level. The images are representative of three separate experiments performed in triplicated. Bars indicate the mean \pm standard deviation of three independent experiments performed in triplicate. ${ }^{*} p<0.05$ compared with zero value, ${ }^{\dagger} p<0.05$ compared with LPS only. TPL: triptolide, LPS: lipopolysaccharide, NF-kB p65: nuclear factor-kappa B p65.

adhesion molecule-1, integrin $\beta 6$, vascular endothelial growth factor, granulocytemacrophage, colony-stimulating factor, GATA-3, fra-1, NF 45를 억제함으로써 항염증 반응 을 일으키는 것이 알려져 있다. ${ }^{14)}$ 또한 LPS로 유도된 급성 폐 손상 쥐 모델 연구에서도 TPL이 항염증 작용이 있으며, ${ }^{15)}$ 천 식 쥐 모델 연구에서는 TPL이 $\mathrm{NF}-\mathrm{kB}$ 경로 활성화를 억제 하여 MUC5AC 발현을 조절함이 밝혀졌다. ${ }^{22)}$

위와 같이 세포와 동물, 사람 실험을 통하여 TPL이 염증 세포와 염증 매개 물질 활성화 조절을 통해 항염증 효과가 있 음이 알려져 있으나, 사람 호흡기 상피세포에서 TPL이 중요 점액 유전자들의 발현에는 어떠한 영향을 미치는지는 아직까 지 명확하게 밝혀지지 않았다. 본 연구에서는 NCI-H292 세 포와 정상 비점막 세포에서 LPS에 의해 증가된 MUC5AC와 MUC5B의 유전자 발현 및 단백 생성이 다양한 농도의 TPL $(25,50,100 \mathrm{ng} / \mathrm{mL})$ 에 의해 억제되었지만 용량 의존적은 아 닌 것을 확인할 수 있었고, 이 억제 효과는 LPS에 의해 유도 된 NF-kB 경로와 관계가 있음을 확인할 수 있었다.

이상의 연구 결과로 보아 사람 호흡기 상피세포에서 TPL이 점액의 과분비를 억제하는 작용이 있으므로, 이와 관련된 작 용기전에 대한 연구와 in vivo 연구를 진행한다면 점액의 과 분비를 억제할 수 있는 새로운 약제의 개발에 도움을 줄 것 으로 생각된다.

\section{REFERENCES}

1) Ali MS, Pearson JP. Upper airway mucin gene expression: a review. Laryngoscope 2007;117(5):932-8.

2) Kim KC. Role of epithelial mucins during airway infection. Pulm Pharmacol Ther 2012;25(6):415-9.

3) Park NK, Choi YS, Lee JH, Kim HS, Kim JK, Ahn JH, et al. Effect of udenafil on MUC5B expression in human airway epithelial cells. Korean J Otorhinolaryngol-Head Neck Surg 2013;56(8):501-5.

4) Lee JG, Moon HJ, Kim SS, Kim CW, Yoon JH. Expression and regulation of MUC8 \& MUC5AC by various cytokines in normal human nasal epithelial cells. Korean J Otolaryngol-Head Neck Surg 2001;44(6):600-5.

5) Song EJ, Bae CH, Kim JY, Kim YW, Park SY, Song SY, et al. Effect of epigallocatechin-3-gallate on PMA-induced MUC5B expression in human airway epithelial cells. Clin Exp Otorhinolaryngol 2013; 6(4):237-42.

6) Lee JH, Kim GO, Na HG, Park NK, Kim HS, Kim JK, et al. Effect of anthocyanidin on MUC5AC and MUC5B expression in airway epithelial cells. Korean J Otorhinolaryngol-Head Neck Surg 2013; 56(5):291-6.

7) Borchers MT, Carty MP, Leikauf GD. Regulation of human airway mucins by acrolein and inflammatory mediators. Am J Physiol 1999; 276(4 Pt 1):L549-55.

8) Kim YD, Kwon EJ, Park DW, Song SY, Yoon SK, Baek SH. Interleukinlbeta induces MUC2 and MUC5AC synthesis through cyclooxygenase-2 in NCI-H292 cells. Mol Pharmacol 2002;62(5):1112-8.

9) Dabbagh K, Takeyama K, Lee HM, Ueki IF, Lausier JA, Nadel JA. IL-4 induces mucin gene expression and goblet cell metaplasia in vitro and in vivo. J Immunol 1999;162(10):6233-7.

10) Hewson CA, Edbrooke MR, Johnston SL. PMA induces the MUC5AC respiratory mucin in human bronchial epithelial cells, via PKC, EGF/ TGF-alpha, Ras/Raf, MEK, ERK and Spl-dependent mechanisms. J Mol Biol 2004;344(3):683-95.

11) Song SY, Seo YJ, Kim YW, Park SY, Bae CH, Kim YD. Effect of Onchocerca volvulus chitinase on MUC5B expression in human airway epithelial cells. Am J Rhinol Allergy 2013;27(1):3-7.

12) Yang S, Chen J, Guo Z, Xu XM, Wang L, Pei XF, et al. Triptolide inhibits the growth and metastasis of solid tumors. Mol Cancer Ther 2003;2(1):65-72.

13) Qiu D, Zhao G, Aoki Y, Shi L, Uyei A, Nazarian S, et al. Immunosuppressant PG490 (triptolide) inhibits T-cell interleukin-2 expression at the level of purine-box/nuclear factor of activated T-cells and NF-kB transcriptional activation. J Biol Chem 1999; 274(19):13443-50.

14) Zhao G, Vaszar LT, Qiu D, Shi L, Kao PN. Anti-inflammatory effects of triptolide in human bronchial epithelial cells. Am J Physiol Lung Cell Mol Physiol 2000;279(5):L958-66.

15) Wei $D$, Huang $Z$. Anti-inflammatory effects of triptolide in LPS-induced acute lung injury in mice. Inflammation 2014;37(4):1307-16.

16) Kim HS, Choi YS, Lee JH, Park NK, Park CH, Lee YH, et al. Effect of betulinic acid on MUC5AC and MUC5B expression in airway epithelial cells. Korean J Otorhinolaryngol-Head Neck Surg 2014; 57(8):526-32.

17) Choi JH, Hwang YP, Han EH, Kim HG, Park BH, Lee HS, et al. Inhibition of acrolein-stimulated MUC5AC expression by Platycodon grandiflorum root-derived saponin in A549 cells. Food Chem Toxicol 2011;49(9):2157-66

18) Lee HJ, Lee SY, Bae HS, Kim JH, Chang GT, Seok JH, et al. Inhibition of airway MUC5AC mucin production and gene expression induced by epidermal growth factor or phorbol ester by glycyrrhizin and carbenoxolone. Phytomedicine 2011;18(8-9):743-7.

19) Kim KD, Lee HJ, Lim SP, Sikder A, Lee SY, Lee CJ. Silibinin regulates gene expression, production and secretion of mucin from cultured airway epithelial cells. Phytother Res 2012;26(9):1301-7. 
20) Takami S, Mizuno T, Oyanagi T, Tadaki H, Suzuki T, Muramatsu $\mathrm{K}$, et al. Glucocorticoids inhibit MUC5AC production induced by transforming growth factor- $\alpha$ in human respiratory cells. Allergol Int 2012;61(3):451-9.

21) Qiu D, Kao PN. Immunosuppressive and anti-inflammatory mechanisms of triptolide, the principal active diterpenoid from the chinese medicinal herb tripterygium wilfordii Hook. f. Drugs R D 2003;4(1):1-18.

22) Chen M, Lv Z, Zhang W, Huang L, Lin X, Shi J, et al. Triptolide suppresses airway goblet cell hyperplasia and Muc5ac expression via NF-kB in a murine model of asthma. Mol Immunol 2015;64(1): 99-105. 